\title{
Three phases of courts' publicity: reconfiguring Bentham's open justice in the twenty-first century
}

\author{
Jane Johnston ${ }^{1 \star}$ \\ ${ }^{1}$ Associate Professor, Faculty of Humanities \& Social Sciences, The University of Queensland \\ ${ }^{\star}$ Corresponding author. E-mail: jane.johnston@uq.edu.au.
}

\begin{abstract}
The paper examines the changing nature of publicity in the courts, tracing three distinct but interconnected phases of publicity using Jeremy Bentham's theory of open justice and publicity as a framework. The first phase is press coverage, with the news media chronicling the justice system for the general population, most recently including televised court proceedings. The second is the appointment of Courts Information Officers, occurring as early as the 1930s and growing in impact since the 1990s, established to facilitate the relationship between courts and the news media. The third and final phase is the Internet, including social media, resulting in changes to news media models and driving contemporary practices of court-generated media. The paper concludes that, while media and communication practices have changed radically since the eighteenth and nineteenth centuries and the concept of publicity has shifted, Bentham's approach to open justice remains salient for twenty-first-century courts' communication.
\end{abstract}

Keywords: open justice; courts; publicity; Bentham; media

\section{Introduction}

Publicity may be 'the very soul of justice' (Bentham, 1843a, p. 316) but would Jeremy Bentham recognise court publicity today? Bentham's much-cited nineteenth-century words have become synonymous with open justice, fundamental to courts and the judiciary laying open their doors, enabling the rule of law to be not only transparent and accessible, but open to external scrutiny. In this paper, I respond to Bentham's call for the utility of publicity in the courts by examining the various methods of publicity that have, over time, provided the public with an understanding of the workings of the courts and the judiciary. Bentham's idea of open justice has been described as a 'comprehensive, relentless, and unavoidable public oversight' (Postema, 2014, p. 43, emphasis in original) achieved through as many avenues of publicity as possible. This, he argued, raised the likelihood that all parties in the court process would be subject to the judgment of the public through the publicity process. Resnik (2013) points out that thinking about courts as an isolated institution is highly problematic, because the mandate that frames the work of the courts also applies to the institutions that facilitate their discursive exchanges with the public and, in so doing, transfers authority to the public. For Bentham, the primary institution tasked with this role was the news media - an institution that continues to report on the workings of the courts but that has undergone radical change since the press of Bentham's time.

I propose that, since Bentham's nineteenth-century writing, the courts have experienced three distinct but interrelated phases of publicity. The first phase is the news media's coverage of courts, beginning with newspaper reporting and developing with broadcast coverage as television became a dominant news medium. The second phase is the move by courts to appoint specialised communication and media staff (called in this paper Courts Information Officers or CIOs), employed as an interface and liaison role between the news media and the courts, including the judiciary. The third phase is 
the development of the independent means of publicity made available to courts by the Internet, most recently through social media, which adds an additional layer of publicity to the two levels already in place. These three phases of publicity have come together in the contemporary communication environment to produce and deliver representations of justice via a plethora of media channels: through television, social media, Internet news, websites, print and radio, using applications (apps), streaming, online and hard copy delivery methods. ${ }^{1}$

In explicating this three-phased approach, I suggest that, while radical changes to media in the twenty-first century have reshaped Benthamite ideas of publicity, and publicity as a single, unequivocal concept has taken on more than one meaning, the thrust of his argument and fierce commitment to courts being made open and accountable remain fundamentally in place. Moreover, though communication methods now radically depart from Bentham's eighteenth- and nineteenth-century life, the philosophy behind his advocacy for publicity via direct observation, access to court documents for persons not physically present in proceedings, the provision of official reports and unfettered access to the press (Resnik, 2013) have, to a large extent, found renewed agency in contemporary media and communication models and methods. Resnik observes:

'Once events are accessible to an audience of third parties who are 'spectators and auditors' (to borrow Bentham's categories), they can put their descriptions and commentary into the public realm. These exchanges are rich, albeit sometimes pain-filled, sources of communicative possibilities.' (Resnik, 2013, p. 26)

I argue that, in the contemporary media environment, communicative possibilities as Bentham might have identified them have become communicative realities. These realities have multiplied and fragmented during the three phases analysed in this paper, generating significant benefits as well as challenges for the courts today.

\section{Three phases of publicity}

The twenty-first century has provided expanded and diversified media opportunities and challenges for the courts. Though restrictions do exist, with some areas emerging as major restricted zones, for instance in terrorism trials, via suppression orders, in alternative dispute resolution or courts outsourcing work (Resnik, 2013), more media channels, dedicated courts' communication staff and even expanded definitions of the role of the journalist (Johnston and Wallace, 2017) provide varied opportunities for more publicity, albeit not always of a positive nature. In investigating this array of media opportunities, I propose that court publicity has occurred in three overlapping phases over time. These are described in this paper as: the press, media liaison and media management. However, before examining these three phases, it is useful to first explore what Bentham meant by the concept of 'publicity' and how it is understood and applied in the twenty-first century.

\subsection{Publicity}

An examination of publicity is deserving of close attention not only due to its fundamental importance to Bentham's writing, but also because the concept has experienced significant shifts in public understanding and usage since the nineteenth century. In the Works of Jeremy Bentham (Bentham, 1843a; 1843b), Bentham examines publicity in the wider political realm (Volume 2) and also the judicial context (Volume 4). ${ }^{2}$ He proposes that the 'fittest law for securing the public confidence [is] publicity' and that there is 'no reason more constant and more universal than the superintendence of the public'

\footnotetext{
${ }^{1}$ I exclude internal communication and court-generated documents for specialised external stakeholder groups such as jurors or lawyers.

${ }^{2}$ Resnik (2013) notes that Bentham used the term 'publicity' synonymously with 'openness' in his sustained examination of the role in a variety of venues, courts included. While this paper follows that general philosophical position, it notes that, over time, this has shifted and there is no single, stable, simplistic definition.
} 
(Bentham, 1843a, p. 310). In keeping with this, he argues, procedures should be as simple as possible in order to enable public opinion to act as a 'direct check' (Resnik, 2013, p. 83) on authority, including government and courts. Bentham's publicity worked in several ways: to ferret out truth, to educate and as a disciplinary or enforcement measure (Resnik, 2013; Postema, 2014) - the latter commonly associated with his idea of the panopticum, outlined below.

Bentham was in good company in mounting an argument for publicity's alignment with open and transparent government. Other political philosophers, including Kant, Mill and, later, Rawls, each had much to say about publicity and where it sits in opposition to secrecy (Gosseries and Parr, 2017), with Bentham calling 'secresy [sic] ... an instrument of conspiracy' (1843b, p. 315). Luban's (1998, p. 155) translation of Kant on publicity explains how his position stemmed from the idea that: 'All actions relating to the rights of other human beings are wrong if their maxim is incompatible with publicity.' He describes Kant's 'publicity principle' as underpinning the ethical question: 'Could I still get away with this if my action and my reason for doing it were publicly known?' (Luban, 1998, p. 156). Publicity thus acts a conceptual framework for determining whether an action would hold up to public scrutiny, thereby providing a test for the legitimacy or justness of public policy (Luban, 1998). Here it is useful to consider Bentham's idea of how public scrutiny can be represented in the panopticum best known through how he envisaged a prison system in which warders could view all cells from a central point; however, Bentham also used the concept to describe public structures and buildings that enabled public enquiry into public affairs, systems and officials (Bentham, 1791; see also Postema, 2014; Resnik, 2013). For his vision, Bentham has been called an 'architect of publicity' (Postema, 2014) because he argued not only that decision-making should be public, but that the physical structures in which these take place should architecturally enable transparency, scrutiny and public accountability to take place. Bentham's concept of the panopticum has been revised many times, in the context of both crime and punishment (Foucault, 1977) and media and society (Doyle, 2011; Mathiesen, 1997). Of particular interest for this paper is Mathiesen's idea of the panopticum in what he called 'the viewer society' through which he poses various examples of 'the many watching the few', notably through mass media. ${ }^{3}$ Others have proposed various theories about the visibility of publicity, such as Thompson's theory of 'mediated visibility' that proposes 'a space shaped not only by the constantly changing technologies that enable words and images to be recorded and transmitted ... but also by the institutions and organisations that have an interest in transmitting this content' (2005, p. 49, emphasis added). Thompson's visibility in many ways parallels Bentham's centring of publicity because visibility via the media gains a special kind of presence, attention and legitimacy in the public arena. Thompson proposes how, through the media, visibility is 'freed from the spatial and temporal properties of the here and now' and, as such, speaks to the representations that Bentham might have envisaged for courts, transporting the workings of these institutions across time and space to the masses. Yet, although this process may capture his proposition that the news media should be able to publicise courts' activity, it departs from the idea that courts' buildings can provide important personal interactions, instead presenting at best a quasi-interaction via mediated platforms. Arguably, Bentham's vision would always include both a face-to-face model of publicity as well as a mediated one.

Yet, despite his general enthusiasm for publicity, Bentham accepted that it could not be absolute. He notes: 'It is not proper to make the law of publicity absolute, because it is impossible to foresee all circumstances in which an assembly may find itself placed' (Bentham, 1843b, p. 315). He uses examples of secret ballots for voting, exceptions for privacy, public decency and state secrets as exceptions to his publicity ideal (Resnik, 2013). Again, we see how courts are represented here, through suppression orders, closed court rulings and other exceptional circumstances to the principle of open justice.

\footnotetext{
${ }^{3}$ Mathiesen also proposed the theory of the synopticum, in which the viewing is done 'together' or 'at the same time' (1997, p. 219) (i.e. simultaneously). This was later critiqued by Doyle (2011) in the context of the surveillance society that arrived with the Internet and particularly Google in which major media organisations 'watch the many'.
} 
There is no doubt that Bentham's ideas of publicity focused squarely on creating openness within progressive, democratic societies. However, over time, this has shifted to mean something quite different. Contemporary understandings of publicity now connect it to propagandist functions, including publicity bureaus of war (see e.g. Casey, 1939) and persuasive communication strategy (Grunig and Hunt, 1984; Stoker and Rawlins, 2005). Stoker and Rawlins (2005) studied the history of the term 'publicity' between 1890 and 1930, noting that, while progressive philosophers had viewed publicity in its capacity for moral reform in government by enabling public scrutiny and to help prevent corruption, the term had evolved into an understanding of strategic communication, co-opted by corporations, political parties and governments to seek public approval. As such, publicity became aligned with self-serving practices, described as 'a weapon used by corporations to control public opinion' (Brown, in Stoker and Rawlins, 2005, p. 177):

'In less than thirty years [between 1890s to 1920s] the definition of publicity had changed from a broad searchlight for exposing excess and corruption to a controlled flashlight illuminating only those practices that corporations wanted the public to see.' (Stoker and Rawlins, 2005, p. 177)

By the 1920s, many writers had adopted the contemporary definition of strategic promotion and media placement (Stoker and Rawlins, 2005). The shift in thinking has been attributed to several key factors: first, a belief that social reform included the promotion of industrial progress and expansion; second, a changing alignment with contemporary understanding of what are 'greater good' outcomes; third, the rise in the power of corporations and trusts; and, fourth, the muckraking journalism of the early twentieth century, which saw changes in the treatment of information, language and commentary, thus channelling a new way of understanding the word (Stoker and Rawlins, 2005).

\subsection{Phase one: the press}

The historic relationship between the courts and the press emerged with the development of the commercial or 'penny' presses of the seventeenth and eighteenth centuries. This also saw the rise of the press and the decline in public court attendance - a shift attributed to a lack of time, opportunity or inclination by members of the public, plus the easy access and rapid dissemination of mass-media reports (Rodrick, 2014). For Bentham, a free press, together with open courts and codified laws, was the method for transferring authority back to the public (Resnik, 2013). For the media - then and now - there are practical, economic and ideological reasons to report on the courts. At a purely functional level, the courts supply the media with a smorgasbord of news stories - a staple in an often otherwise unpredictable line-up of daily events. The courts provide free, easy access to news stories, from lengthy trials in the Superior Courts to the daily list of short appearances in the local or magistrates' court. Court cases include readymade narratives, inclusive of quotes, dialogue and characters (Brooks, 2006; Johnston and Breit, 2010), also described as 'an alternative media' due to the news media's direct observational capacity within the courts (Bourke, 2007, p. 7). They include important news components or 'news values' - in particular, conflict, drama, novelty, prominence, proximity and often much more. ${ }^{4}$ Studies of the US Supreme Court have identified news values or newsworthy components that include case origin, court behaviour, issue area, case participants and case salience to explain coverage by the news media (LaRowe and Hoekstra, 2014; see also Davis, 1994, p. 22). As such, these are not simply media drivers - research has found a significant overlap between journalists' assessment of newsworthiness and the long-term legal significance of a case (LaRowe and Hoekstra, 2014).

In addition to the easy stream of news stories that, for the most part, are open and freely accessible to the media, there is a second major component to the news media's coverage of courts centring on journalism's service orientation, fourth estate and social responsibility functions that are fulfilled by

\footnotetext{
${ }^{4}$ For a full discussion of news values, see the original concept by Galtung and Ruge (1965), updated by Harcup and O'Neill (2016); see also Chibnall (1977) specifically in the context of Law-and-Order News.
} 
reporting on democratic institutions (see Rodrick, 2014; Schultz, 1994; Siebert et al., 1956). As former Chief Justice of the High Court of Australia, Gerard Brennan noted the news media and the courts come together to serve 'disparate but interlocking functions' of modern democratic systems (Brennan, 1997), with the relationship typified by a curious mix of tension and co-operation (Chibnall, 1977; Davis, 1994; Johnston, 2005; Moran, 2014b; Rowbotham et al., 2013).

In recent decades, two major changes to the news media's interface with the courts have occurred: first, radical challenges to traditional models of journalism have seen the press, particularly newspapers, impacted by what has been described as an 'ec-tech squeeze ... the simultaneous and increasing pressures' of economic and technological forces (Anderson and Ward, 2007, p. 57). This global costcutting and journalist-shedding has resulted in decreasing numbers of journalists employed on newspapers, including a reduction in specialist court reporters (see e.g. Greenslade, 2016; Moran, 2014b). At the same time, another shift in media attention to the courts has occurred, notably in rising interest from television news and what has become known as the push for 'cameras-in-court' (Cohn and Dow, 1998; Davis, 1994; Stepniak, 1998). This second change has represented a new era of publicity for the courts, in which some jurisdictions have allowed access and others have flatly refused, but which has nevertheless disrupted the status quo of print-dominated court reporting of the past. Stephen Parker's report into the Courts and the Public took a critical look at arguments for allowing cameras into courts in Australia, comparing courts publicity two centuries apart, determining: 'The nature of society and or communications have changed so much between the eighteenth and the twentieth centuries that the traditional means of the courts' communications with the public is (now) badly out of step' (Gamble and Mohr, in Parker, 1998, p. 22). Parker said that communication change should not be left to develop at its own pace in the hope that truth and transparency would somehow prevail - that courts needed to take a proactive stance in their communication with the public (1998). This sentiment was echoed in a large body of literature from the US, Australia, Britain and elsewhere that examined the pros and cons of camera access from the 1990s onward (Cohn and Dow, 1998; Davis, 1994; Stepniak, 1998; Linton and Gerace, 1990; Supreme Court of Queensland, 2016). One recent report, Electronic Publication of Court Proceedings, reviewed the issue in light of the decades of analysis. It argued that public confidence in the judicial system could be assisted by televised access but that this should be considered alongside one relatively simple move - the appointment of a dedicated court medialiaison person to facilitate the process (Supreme Court of Queensland, 2016).

\subsection{Phase two: media liaison}

The rise in television interest in bringing cameras into courtrooms thus represented one driver for the courts to appoint a dedicated liaison role that could facilitate access for this purpose. But the development of the role centred just as much on accuracy as access. Moran (2014b) points to diminished accuracy that resulted from the reduction of dedicated, specialist court reporters. Courts media officers were the judiciary's response to improving the accuracy of news reports, marking a more reliable and systematic flow of information to the public via the news media, television included. This reinforced earlier literature that confirmed the benefits of the media-liaison role in enhancing access and accuracy (Fife-Yeomans, 1995; Ginsburg, 1995; Johnston, 2005; 2008; Parker, 1998). Other reasons also contributed to the push for such appointments. One of these was the growing and heightened criticism of the judiciary, with one Australian researcher noting:

'it seems no coincidence that the courts began to focus on their own communications practices as the media in the 1980s turned their focus to investigations and critical examinations of not just the parliament but also ... the judiciary.' (Johnston, 2005, p. 79)

In Australia, this coincided with the Attorney General changing the official position on defending the judiciary (Rodrick, 2014). Former Australian Attorney General Daryl Williams declared that it was not his job to step in and defend the courts and the judiciary (Williams, 1994). 
Moran (2014a) confirms a similar rise in media criticism of the judiciary in England, connecting this with the twenty-four-hour news cycle: 'an age of instant news, an age in which there is generally a lack of reverence' (Moran, 2014a, p. 203). The development of the CIO role was thus seen to respond to a previous lack of facilitation by the courts with the media: the need to 'bridge the divide' between the courts/ judiciary and the increasingly critical and under-resourced media (Johnston, 2008; Moran, 2014a; see also McGarvie, 1992). Peleg and Bogoch (2014) highlight the importance of the liaison role in other countries, in Israel for instance, where it is expressly forbidden for judges to make direct contact with the media.

However, while the $\mathrm{CIO}$ was generally regarded positively, reservations and concerns were expressed over potential conflicts of interest or lack of understanding in interpreting courts' decisions. Ericson, Baranek and Chan cited problems with the use of official media-sources in the courts:

'Such a person would add another level of interpretation and translation to the process and, as such, would entail 'second-guessing' what went on in court or what was meant by the judge who wrote the judgment. Moreover, there is always a risk that, instead of patrolling the facts, this person might venture into the back regions of the courts on behalf of reporters to reveal the workings there.' (Ericson et al., 1989, p. 37)

The idea of judgment summaries was also a cause for concern (Keyzer, 1999; Moran, 2014b). Moran (2014b) suggests two challenges in developing judgment summaries: the first was a perception that something might be lost in the summary due to emphasis or focus; the second relates to practical difficulties in writing a short summary out of a lengthy document. Ultimately, however, these concerns appear to have been managed, in part at least, through internal checking mechanisms plus the close working relationships between the CIO and the judiciary (Johnston, 2017b; Moran, 2014b; Peleg and Bogoch, 2014). Overall, the volume and level of criticism about the development of the CIO role have been relatively small when compared with the positive responses (Davis, 1994; Johnston, 2005; 2008; Moran, 2014a; 2014b; Peleg and Bogoch, 2014). And, since those early concerns were raised, many jurisdictions have moved to make CIO appointments. ${ }^{5}$ This has, however, spanned many decades.

The earliest recorded official media-liaison appointment was with the US Supreme Court in the 1930s (Newland, 1964). Until 1947, the position was filled by an employee in the clerk's office who was trained in law; this changed to a trained journalist after that time (Newland, 1964). Newland explained that the role was identified not as a press officer, but rather as a public information and service officer for reporters and other members of the public. As the role developed elsewhere, the public information element was also highlighted, with distinctions away from overt public relations and an importance placed on the title of the person in the role. One North American media officer differentiated the work of the courts from other government public relations officers, noting 'we do not do spin' (House, in Ginsburg, 1995, p. 2122), while Davis's (1994, p. 47) examination of the US Supreme Court identified how the press relations arm 'disassociated itself from media manipulation. In Australia, similar sentiments applied, as courts rejected the idea that their job primarily involved public relations or propaganda (Johnston, 2008). This distinction is noteworthy in terms of how publicity has been seen in the courts, with the preferred view as one of facilitator and enabler of open justice rather than one that proactively seeks to manage a message. The distinction between 'public information' and 'public relations' as it applies to publicity thus takes on a significance for the courts - an issue I will return to later in the paper.

The CIO role (irrespective of name) - was to see the establishment of formal and informal mechanisms for developing the relationship between courts, the media and the public. Websites were among the first Internet-centred tools. Peleg and Bogoch (2014) report that nearly every constitutional court in the US and Europe maintains a website that includes pending actions; some also include judicial

\footnotetext{
${ }^{5}$ For examples and more details, see: in the US, the Conference of Courts Public Information Officers (CCPIO) member site at https://www.ccpio.org/about/members/ (accessed 23 July 2018); in the UK, Moran (2014a; 2014b); in Australia, Johnston $(2016 ; 2017 a)$.
} 
biographies, administrative reports and historical reviews of the judiciary's constitutional jurisdiction. Upwards of 70 per cent of the constitutional courts in Europe and the Americas produce press releases announcing key courts resolutions; some jurisdictions employ retired judges as 'press judges' who provide explanations and answer questions about current rulings in high-profile cases (Peleg and Bogoch, 2014). A report commissioned by the Queensland Supreme and District Courts in Australia, following a one-year trial of their CIO appointment, found that, in addition to accuracy and access, the role had played a positive part in advancing public understanding of courts and the administration of justice and contributing towards court transparency (Johnston, 2017b, p. 8). Overwhelmingly, it found the CIO had streamlined the work of the media, establishing clear and simple procedures and practices. Moreover, the CIO's work directly with and answering to the judiciary meant strong professional relationships had developed (Johnston, 2017b, p. 15). One of the elements investigated in the Queensland study was whether or not social media should be incorporated into the role. It was generally agreed that this would be a positive development, consistent with developments elsewhere (Davey et al., 2010; 2014; Johnston, 2017a; Meyer, 2014). This brings us to the third and final phase of publicity: managing media from within the courts, inclusive of the continued adaptation to the Internet and the need to consider social media in the communication mix.

\subsection{Phase three: media management}

The appointment of CIOs therefore occurred over many decades, from the 1930s onwards, with new positions still being created well into the 2000s and 2010s (see Alemanno and Stefan, 2014; Johnston, 2017a; 2017b; Moran, 2014b; 2016). But, while earlier and ongoing adjustments for traditional news media (central to phase two) had been 'metered, negotiated, and incremental' under the CIOs guidance (Johnston, 2017a, p. 671), this approach was to prove more difficult in the rapid-paced, changing social-media environment. ${ }^{6}$ The US Conference of Court Public Information Officers and National Center for State Courts pointed to major technological, institutional and cultural differences:

- 'New media are decentralised and multidirectional, while the courts are institutional and largely unidirectional.

- New media are personal and intimate, while the courts are separate, even cloistered, and, by definition, independent.

- New media are multimedia, incorporating video and still images, audio and text, while the courts are highly textual.' (Davey et al., 2010 p. 7)

Nevertheless, expectations by courts, especially in the US, began to focus more on 'when' rather than 'if social media would be adopted, as outlined in the report by the National Center for State Courts:

'For years courts have struggled with media relations. From whether to allow cameras in the courtroom to how to respond to a reporter's questions, the questions often outnumber the answers to issues that arise. With the explosion of social media, courts must now decide not if we will embrace social media but when and to what degree.' (Slayton, 2011, p. 34)

Over a five-year period - from 2010 to 2015 - increased use of social media by courts in the US and, to some extent in Australia, Britain and Europe, saw a shift from perceptions of a 'future' inevitability of social-media use to actual, sometimes advanced, levels of adoption (Alemanno and Stefan, 2014; Davey et al., 2010; 2014; Jackson and Shelly, 2015/16; Johnston, 2012; 2017a; Meyer, 2014; Moran, 2016; Slayton, 2011).

\footnotetext{
${ }^{6}$ Social media were to gain momentum from the early 2000s, with the launches of Facebook in 2004, YouTube in 2005 and Twitter in 2006.
} 
Within this final phase of publicity, we need to take a step back and review the media world that the courts were now forced to navigate. Media theorist Mark Deuze describes contemporary society as embedded in 'media life' (2012a). More than half the world's total population use the Internet only twenty-five years after it was first made available for public use - while 37 per cent of the world's population uses social media (We Are Social, 2017). In some countries, the statistics are much higher nearly 80 per cent of Australian adults use social media (Sensis, 2017), around 70 per cent of US adults (Pew Research Center, 2017) and 64 per cent of British adults (with 99 per cent usage by those aged sixteen to twenty-four years) (Elder, 2016). In this environment, then, courts were deciding whether to increase their public visibility, with the CIOs now able to proactively seek out publicity, using their own channels of communication, while at the same time addressing the needs of the news media that were also in the process of change.

Phase three therefore was to bring both major challenges and opportunities to the courts. Opportunities occurred primarily at two levels: first, in phase two, CIOs had already begun establishing an online court presence through facilitating websites, online summaries, streaming of judgments, virtual tours of court facilities, judicial profiles, media guidelines, press releases and so on. These publicity tactics provided not only informational, but educative functions, as well as directly assisting the news media with its job. Phase three also saw an additional layer of communication platforms become more widely adopted in courts, following government and business, with the use of social-media networking. The uptake of Twitter, YouTube and other platforms took communication one step further, introducing a proactive, dynamic and potentially conversational set of tools, inviting some degree of interaction from others. In this context, social media provide self-generated mediated communication that can go beyond a static 'information out' source in this third phase of publicity, with the CIO acting as a pivot point between courts and external publics (Johnston, 2016). Social media (arguably) force a more dialogic style of communication, ${ }^{7}$ both in dealing with the news media and in bypassing it via courts own internally generated media, thus allowing courts to more easily and proactively manage their own message. This basic principle of communication management, enabled by social media, has provided an evening-out of the power differential whereby the media controlled the principal, sometimes only, means of active public interface for the courts. The shift from heavy reliance on 'mass media' (seen via traditional news channels) to 'owned' media ${ }^{8}$ (seen via internally driven media channels) is consistent with research that finds that, although the mass media still play an important role in professional organisational communication, varying across industries and countries, there has been a significant shift in emphasis towards 'owned' and internally managed media (Verčič and Verčič, 2016; Zefass et al., 2016). And so, if the appointment of CIOs was a first step to assist with court publicity, the adoption of owned media and the potential for shared media have been a significant second step. While this has not occurred at the same level as, for example, in the police sector (see Lee and McGovern, 2013), in introducing social media, many CIOs have most certainly advanced the institutional communication advantage and enhanced the degree of openness, albeit on a limited scale.

However, within this media life, there are also challenges. These occur in the disruptions that emerge from additional actors, both inside and outside the courtroom, including the blurring of boundaries around those who are now to be counted as 'journalists' in the eyes of the courts. With the rise of bloggers and non-traditional journalists, "the distinction between the "media" and the "public" is now not always an easy one to draw' (Wallace and Johnston, 2015, p. 21). As a result, courts are giving serious attention to the day-to-day media-reporting practices from inside the courtroom as they reassess 'who is a journalist' and 'what is the news media' in instances that have historically fallen to specialist news reporters, especially those trained in court reporting laws and practices. This issue has

\footnotetext{
${ }^{7}$ The question of true 'dialogic' courts' social media can vary from platform to platform. For example, courts' YouTube channels often do not allow comment, yet Twitter's 'retweet' and 'like' functions are usually enabled.

${ }^{8}$ Owned media are one of four types of media in the contemporary media formula of 'PESO', made up of: Paid (Advertising), Earned (news and social mentions), Shared (any mixture of paid, owned and earned) and Owned (websites, press releases and other organisational media). See Dietrich (2014).
} 
come to the attention of courts internationally, with questions surrounding media training, accreditation, legal knowledge and employer responsibility (Gleason, 2015; Johnston and Wallace, 2017; Peters and Tandoc, 2013; Wallace and Johnston, 2015; West, 2014) occurring concurrently with reductions in specialist court reporters (Greenslade, 2016; Moran, 2014b). Questions are raised: How do court reporting guidelines for journalists apply to those who choose to report but do not identify with journalism in other ways, such as adhering to a code of ethics? And, how are guidelines enforced? If a lack of training and expertise has been found to be a growing issue within traditional, employed journalists' ranks, this growing phenomenon of the 'non-traditional' journalist represents as big a challenge for the courts. Guidance documents and practice directions have been developed by CIOs to address the issue across many countries and jurisdictions, for example in England and Wales (Judge, 2011), Australia (Johnston and Wallace, 2017), the US (Supreme Judicial Court Rule 1.19, 2012: part 2), Canada (Canadian Centre for Court Technology, 2013) and Hong Kong (Ma, 2014). In most cases, the guidelines outline whom the courts recognise as journalists and this also applies to using Twitter (or live text-based communication) from courts (Johnston and Wallace, 2017).

Finally, one of the biggest challenges for the courts to have emerged with social media has come from the general public, who can post material from anywhere, anytime. In short, the public, formerly acting as the audience, is now an active media producer in its own right. As Keyzer and colleagues note: 'Social media has created intense challenges for the law and judicial administration' (Keyzer et al., 2013, p. 47). Their study of judges and court workers found those in the judiciary and court administration were concerned with a range of issues, among them: juror misuse of social media leading to aborted trials, sub judice issues and breaches of suppression orders (by tweets, Facebook or other social media) that 'go viral' and misrepresentations of court work and activity to a community that may not understand the processes or issues involved (Keyzer et al., 2013, p. 48).

In sum, social media's pervasiveness and reach most certainly hold great potential for courts, but the complex and changed media ecosystem of today is fraught with issues that Bentham could not have envisaged. Overwhelmingly, one of the biggest single changes has been the blurring of the role of the media consumer and producer, ${ }^{9}$ with the capacity for individuals to communicate with many across the multimedia landscape. At the same time, the traditional or legacy media's stranglehold on what is published and prioritised in the news agenda has been significantly impacted. The changes have also brought another level of meaning to the concept of 'pre-trial publicity', previously associated with traditional media, but now shared with the pervasive and ubiquitous social-media environment. I will now review Bentham's publicity imperative in light of the issues raised in the three phases examined here.

\section{Publicity and the courts: a critical reflection}

Earlier this century, Canada's Chief Justice Beverley McLachlan provided an evocative description of the modern courts as they relate to Bentham's concepts of publicity, open justice and its actors. She noted:

'Much has changed since Bentham's time. The courtroom scene, however, remains remarkably similar. An observer from the 19th Century would have no difficulty recognising the players in the modern courtroom. Behind the bench sits the judge. At the counsel table sit the lawyers. The witness sits in the witness box and the parties listen from pews behind the bar. Sometimes members of the public ... join the parties in the audience. And, occasionally, usually in the public seats but sometimes at a special bench to one side, one finds a member of the press. This is how things were in Bentham's time, and this is how, by and large, they remain.' (McLachlan, 2003, para. 2)

But, while the observer might find the physical courtroom and its participants similar, behind the scene or even hidden within may lie a different story. The reporter might be a blogger, television

\footnotetext{
${ }^{9}$ Titles such as 'produser' have emerged to describe the convergent nature of the new producer-consumer.
} 
cameras might be discreetly hidden, there will likely be fewer members of the public in attendance than in Bentham's day and a CIO might appear as a member of the audience, observing and managing aspects of a high-profile trial. Justice McLachlan's words remind us that the world around the courts has radically changed, while changes within courts' structures have been far more subtle.

In presenting some of the major external changes in the media and communication environment, and their application to and impact on the courts, this paper has not intended to generalise the three phases of publicity across all courts, but rather to underscore certain trends that have occurred in many jurisdictions, (re)configuring the notion of publicity over two centuries and, in doing so, provide a framework for reflecting on Bentham's ideas of publicity and open justice. Bentham's ideas of publicity remain useful in providing a normative way of framing public agency, transparency and openness and, indeed, the term retains currency in legal literature where it continues to be associated with open justice and the rule of law (see e.g. Luban, 1998; McLachlan, 2003; Postema, 2014; Resnik, 2013; Rodrick, 2014; Spigelman, 2006). However, a more pragmatic, self-interested world of mediatisation and public-image management has, in populist traditions at least, changed the general understanding of what is meant by publicity. Scholars have sought ways to distinguish between the two meanings as they apply to communication practice: L'Etang (2004), for example, identifies the negative associations with advocacy and the positive with public information and social responsibility; Johnston associates courts' publicity with public-interest communication (Johnston, 2016).

Moreover, two major interconnected changes in the media and communication sectors have occurred since Bentham's nineteenth-century musings, which have significantly impacted on courts and judicial publicity and representations. The first is the rapid and dramatic development of organisational communication management; the second is the radical and pervasive changes to media. In practice, these changes underpin the second two phases of publicity outlined in this paper, and provide a context for the necessary changes to phase one.

\subsection{The rise in institutional communication and public information}

This role is enabled in courts in the specialised role of the CIO. The fields of public relations and communication have chronicled changes in institutional-media relationships (see e.g. Zefass et al., 2016; Verčič and Verčič, 2016) and, although courts have eschewed certain titles such as public relations in the past, this literature is nevertheless instructive. Verčič and Verčičs's (2016) analysis of the changing relationship between public relations and the news media clearly parallels the second and third phases of publicity examined in this paper. They argue that public relations initially enabled organisations to become reflexive to news media expectations and adjust their behaviours to journalistic needs. However, the dominance that was once held by the traditional news media has waned. This represents a shift from fewer than one public relations practitioner per one journalist in 1960 to five public relations practitioners per one journalist in 2010 (Verčič and Verčič, 2016). With this trend in mind, it is no surprise that many courts were to follow the trend, albeit in many jurisdictions well after other arms of government and the corporate sectors, to appoint official information and media personnel, found in the CIO role. This juxtaposed against a number of other social, political and economic drivers, including the rise in media criticism of the judiciary, changes to media structures and reporting patterns, a reduced speciality in court reporting and the shift to television and Internet media dominance; each provided fertile ground for courts to make the move to the specialist communication and media appointments this paper has outlined. They also, most certainly, coincided with the shift in how we understand publicity today.

\subsection{The radical and pervasive changes to media}

These are characterised by altered media models, a downsizing of traditional media and the rapid growth of the Internet and social media. These changes to media technologies cannot be overstated in the evolution of the three phases of courts' publicity. The question was posed at the start of the 
paper: would Bentham recognise publicity today? In response, and in conclusion to this paper, some aspects of media have changed so dramatically that he certainly would not recognise them, yet his saturation approach to publicity and open justice, from all directions, in holding public institutions to account is not inconsistent with the pervasive and all-consuming contemporary media that are characterised by both the panoptic and the synoptic systems outlined in this paper. These include all possible media interactions: the traditional mass-media model of 'one to many' (e.g. television); the social-media option of 'one to many', as seen in courts-owned media (e.g. Twitter); or the social-media option of 'many to many', as seen in the community's capacity to publish and share their commentary broadly (e.g. Facebook and Twitter).

Several media theories provide some scaffolding here. Deuze (2012b) argues that media are 'fused' with everything we do; he goes so far as to suggest that we can only imagine life outside media. Media are thus seen as both content and platform: what is communicated and how it is communicated, both necessary and unavoidable (Deuze, 2012a). In a similar way, the theory of mediatisation (or mediatisation) suggests that media have become so fundamental and integral in human life and experience that, when considered at the extreme, society is not separated from the media at all: 'The mediated reality becomes more important than the actual reality, in the sense that it is the mediated reality that people have access to and react to' (Strömbäck, 2008, p. 238). This is true for the courts - the mediated reality that comes from the news media or, increasingly, the courts' own media are how most people come to know courts.

Mediatisation also focuses on the influence media exert on society and culture and the way politics adapts to use the media. In this way, mediatisation is defined as 'processes whereby the logic and institutionalised norms of the media affect the behaviour of actors and institutions belonging to other societal subsystems' (Laursen and Valentini, 2015, p. 28). This adaptation fits the political environment, illustrated in the 2016 US presidential election and the rise of what has become known as 'Fake News'. However, in the context of courts, it provides reason for pause. It sheds light on why courts may have been slower to adopt new forms of media, engage at the same level as other institutions or, in other words, become 'mediatised'. The theory provides an explanation for why judges who openly advocate strong working relationships with the news media, and the adoption of proactive, internally driven media and the role of the CIO, nevertheless argue for the need to keep a degree of professional distance (Brennan, 1997; Rodrick, 2014; Stack, 1998; Drechsel, 1983; Keyzer, 1999; Habermas, 1989). The risk, otherwise, as we reflect upon issues raised in this study, is that a fourth phase of publicity could materialise - a phase that adopts an overly 'mediatised' approach. Such a shift by courts that took on 'media logics' or became driven by news values might be seen as a slippery slope of publicity that even Bentham might not recognise.

\section{References}

Alemanno A and Stefan O (2014) Openness at the court of Justice of the European Union: toppling a taboo. Common Market Law Review 51, 97-140.

Anderson PJ and Ward G (2007) The Future of Journalism in the Advanced Democracies. Aldershot: Ashgate Publishing. Bentham J (1791) Panopticon; or the Inspection House. London: T Payne.

Bentham J (1843a) An essay on political tactics. In Bowring J (ed.), Works of Jeremy Bentham, Vol. 2. Edinburgh: William Tait, pp. 310-316. Available at http://oll.libertyfund.org/titles/bentham-the-works-of-jeremy-bentham-vol-2 (accessed 21 July 2018).

Bentham J (1843b) Works of Jeremy Bentham, Vol. 4. Edinburgh: William Tait, pp. 305-407. Available at https://books.google. com.au/books?id=QdEQAAAAYAAJ\&printsec=frontcover\&source=gbs_ge_summary_r\&cad=0\#v=onepage\&q\&f=false (accessed 15 September 2017).

Bourke JF (2007) The role of Australian courts as alternative media. In Chitty N and Rattikalchalakorn S (eds), Alternative Media: Idealism and Pragmatism. Penang: Southbound Press, pp. 51-62.

Brennan G (1997) The Third Branch and the Fourth Estate, paper presented at the Broadcasting, Society and the Law, University College of Dublin, 22 April 1997. Available at http://www.hcourt.gov.au/publications/speeches/former/ speeches-by-the-hon-sir-gerard-brennan (accessed 21 July 2018).

Brooks P (2006) Narrative transactions - does the law need a narratology? Yale Journal of Law \& the Humanities 18, 1-28. 
Canadian Centre for Court Technology (2013) Canada-Wide Summary of Court Policies on Live Text-Based Communications from the Courtroom. Available at http://www.adidem.org/images/e/e4/Policies-on-Live-Text-BasedCommunications-June-2013.pdf (access 1 October 2017).

Casey RD (1939) The National Publicity Bureau and British Party Propaganda. Public Opinion Quarterly 3, $623-634$.

Chibnall S (1977) Law-and-Order News. London: Tavistock.

Cohn M and Dow D (1998) Cameras in the Courtroom: Television and the Pursuit of Justice. Jefferson, NC: McFarland \& Co.

Davey C et al. (2010) New Media and the Courts: The Current Status and a Look at the Future, Conference of Court Public Information Officers 19th annual meeting, Atlanta, Georgia, 26 August 2010. Available at http://ccpio.org/wp-content/ uploads/2012/02/2010-ccpio-report-summary.pdf (accessed 28 September 2017).

Davey C et al. (2014) CCPIO New Media Survey: A Report of the Conference of Court Public Information Officers, Conference of Court Public Information Officers 23rd annual meeting, Las Vegas, Nevada, 6 August 2014. Available at http://ccpio. org/wp-content/uploads/2014/08/CCPIO-New-Media-survey-report_2014.pdf (accessed 28 September 2017).

Davis R (1994) Decisions and Images: The Supreme Court and the Press. Englewood Cliffs: Prentice Hall.

Deuze M (2012a) Deuzeblog: Media Life. Available at http://deuze.blogspot.com.au/2011/10/media-life-2012-preface.html? view=magazine (accessed 10 June 2017).

Deuze M (2012b) Media Life. Cambridge: Polity Press.

Dietrich G (2014) Spin Sucks: Communication and Reputation Management in the Digital Age. Indianapolis, IN: Pearson Education.

Doyle A (2011) Revisiting the synopticon: reconsidering Mathiesen's 'The Viewer Society' in the age of Web 2.0. Theoretical Criminology 15, 283-299.

Drechsel R (1983) News Making in the Trial Courts. New York: Longman.

Elder R (2016) 99\% of young British people use social media every week, Business Insider, 5 August. Available at http://www.businessinsider.com/99-of-young-british-people-use-social-media-every-week-2016-8/?r = AU\&IR (accessed 26 September 2017).

Ericson R, Baranek P and Chan J (1989) Negotiating Control: A Study of News Sources. Toronto: University of Toronto Press.

Fife-Yeomans J (1995) Fear and loathing: the courts and the media. Journal of Judicial Administration 5, 39-42.

Foucault M (1977) Discipline and Punish: The Birth of the Prison. New York: Pantheon Books.

Galtung J and Ruge MH (1965) The structure of foreign news: the presentation of the Congo, Cuba and Cyprus crises in four Norwegian newspapers. Journal of Peace Research 2, 64-90.

Ginsburg RB (1995) Communicating and commenting on the court's work. The Georgetown Law Journal 83, 2119-2129.

Gleason T (2015) If we are all journalists can journalistic privilege survive? Journal of the European Institute for Communication and Culture 22, 357-386.

Gosseries A and Parr T (2017) Publicity. In The Stanford Encyclopedia of Philosophy. Available at https://plato.stanford.edu/ archives/fall2017/entries/publicity (accessed 16 September 2017).

Greenslade R (2016) New studies suggest continuing decrease in court reporting, The Guardian, 29 October. Available at https://www.theguardian.com/media/greenslade/2016/oct/28/new-studies-suggest-continuing-decrease-in-court-reporting (accessed 25 September 2017).

Grunig JE and Hunt T (1984) Managing Public Relations. New York: Holt, Rinehart \& Winston.

Habermas J (1989) The Structural Transformation of the Public Sphere: An Inquiry into a Category of Bourgeois Society. Cambridge: MIT Press.

Harcup T and O'Neill D (2016) What is news? Galtung and Ruge revisited (again). Journalism Studies 18, $1470-1488$.

Jackson M and Shelly M (2015/16) The use of Twitter by Australian courts. Journal of Law Information and Science 24, 83-100.

Johnston J (2005) Communicating courts: a decade of practice in the third arm of government. Australian Journal of Communication 32, 77-93.

Johnston J (2008) The court-media interface: bridging the divide. Australian Journalism Review 30, 27-39.

Johnston J (2012) Courts new visibility 2.0. In Keyzer P, Johnston J and Pearson M (eds), Courts and the Media in the Digital Age. Sydney: Halstead Press, pp. 41-54.

Johnston J (2016) Public Relations and the Public Interest. New York: Routledge.

Johnston J (2017a) Courts use of social media: a community of practice model. International Journal of Communication 11, 669-683.

Johnston J (2017b) Review of the Court Information Officer Position. Brisbane: Queensland Supreme and District Courts (unpublished report).

Johnston J and Breit R (2010) Towards a narratology of court reporting, Media International Australia 137, 47-57.

Johnston J and Wallace A (2017) Who is a journalist? Changing legal definitions in a de-territorialised media space. Digital Journalism 5, 850-857.

Judge Lord (2011) Practice Guidance: The Use of Live Text-Based Forms of Communication (including Twitter) from Court for the Purposes of Fair and Accurate Reporting, The Lord Chief Justice of England and Wales, 14 December. Available at http://www.judiciary.gov.uk/wp-content/uploads/JCO/Documents/Guidance/ltbc-guidance-dec-2011.pdf (accessed 1 July 2016). 
Keyzer P (1999) What the courts and the media can do to improve the standard of media reporting of the work of the courts. In Keyzer P (ed.), The Courts and the Media. Rushcutters Bay, NSW: Halstead Press, pp. 150-158.

Keyzer P et al. (2013) The courts and social media: what do judges and court workers think? Judicial Officers' Bulletin 25, 45-51.

L'Etang J (2004) Public Relations in Britain. Mahwah, NJ: Lawrence Erlbaum.

LaRowe N and Hoekstra V (2014) On and off the Supreme Court beat: differences in newspaper coverage of the Supreme Court and the implications for public support. In Davis R (ed.), Covering the United States Supreme Court in the Digital Age. Cambridge: Cambridge University Press, pp. 126-152.

Laursen B and Valentini C (2015) Mediatization and government communication: press work in the European Parliament. The International Journal of Press/Politics 20, 26-44.

Lee $\mathbf{M}$ and McGovern A (2013) Force to sell: policing the image and manufacturing public confidence. Policing and Society 23, $103-124$.

Linton JM and Gerace M (1990) The reel world of the courtroom: an analysis of a television documentary about a murder trial. Windsor Yearbook of Access to Justice 10, 127-150.

Luban D (1998) The publicity principle. In Goodin RE (ed.), The Theory of Institutional Design. Cambridge: Cambridge University Press, pp. 154-198.

Ma G (2014) The Use of Information Technology and Text-Based Communications in Courtrooms, Practice Direction no. 32, Hong Kong. Available at http://legalref.judiciary.gov.hk/doc/npd/eng/PD32.htm (accessed 1 October 2017).

Mathiesen T (1997) The viewer society: Michel Foucault's 'panopticon' revisited. Theoretical Criminology 1, $215-234$.

McGarvie RE (1992) The ways available to the judicial arm of government to preserve judicial independence. Journal of Judicial Administration 1, 236-280.

McLachlan B (2003) Courts, transparency and public confidence - to the better administration of justice. Deakin Law Review 8. Available at http://www.austlii.edu.au/au/journals/DeakinLawRw/2003/1.html (accessed 26 September 2017).

Meyer N (2014) Social media and the courts: innovative tools or dangerous fad? A practical guide for court administrators. International Journal for Court Administration 6, 1-27.

Moran LJ (2014a) Managing the 'critical interdependencies' of the media and the judiciary in the United Kingdom. In Asimow M, Brown K and Papke DR (eds), Law and Popular Culture: International Perspectives. Cambridge: Cambridge Scholars Publishing, pp. 194-215.

Moran LJ (2014b) Managing the news image of the judiciary: the role of judicial press officers. Oñati Socio-legal Series [online] 4, 799-818. Available at http://ssrn.com/abstract=2506601 (accessed 20 September 2017).

Moran LJ (2016) Visible justice: YouTube and the UK Supreme Court. Annual Review of Interdisciplinary Justice Research 5, 223-263.

Newland CA (1964) Press coverage of the United States Supreme Court. The Western Political Quarterly 17, 15-36.

Parker S (1998) Courts and the Public. Melbourne: Australasian Institute of Judicial Administration.

Peleg A and Bogoch B (2014) Silence is no longer golden: media, public relations and the judiciary in Israel. Oñati Socio-legal Series [online] 4, 819-835. Available at http://opo.iisj.net/index.php/osls/article/viewFile/332/474 (accessed 21 July 2018).

Peters J and Tandoc EC (2013) 'People who aren't really reporters at all, who have no professional qualifications': defining a journalist and deciding who may claim privileges. NYU Journal of Legislation and Public Policy Quorum 34, 34-63.

Pew Research Center (2017) Social Media Fact Sheet. Available at http://www.pewinternet.org/fact-sheet/social-media/ (accessed 27 September 2015).

Postema GJ (2014) The soul of justice: Bentham on publicity, law and the rule of law. In Zhai X and Quinn M (eds), Bentham's Theory of Law \& Public Opinion. Cambridge: Cambridge University Press, pp. 40-62.

Resnik J (2013) The democracy in courts: Jeremy Bentham, 'publicity', and the privatization of process in the twenty-first century. No Foundations: An Interdisciplinary Journal of Law \& Justice 10, 77-119.

Rodrick S (2014) Achieving the aims of open justice? The relationship between the courts, the media and the public. Deakin Law Review 19, 123-162.

Rowbotham J, Stevenson K and Pegg S (2013) Crime News in Modern Britain: Press Reporting and Responsibility, 18202010. Basingstoke: Palgrave.

Schultz J (1994) Not Just Another Business: Journalists, Citizens and the Media. Sydney: Pluto Press.

Sensis (2017) The Must-Know Stats from the 2017 Sensis Social Media Report. Available from https://www.sensis.com.au/ about/our-reports/sensis-social-media-report (accessed 26 September 2017).

Siebert FS, Peterson T and Schramm W (1956) Four Theories of the Press. Urbana: University of Illinois Press.

Slayton DW (2011) Social media: a new way to communicate that can no longer be ignored. In National Center for State Courts (ed.), Future Trends for State Courts, p. 34. Available at http://www.ncsc.org/ /media/Microsites/Files/Future\% 20Trends/Author\%20PDFs/Slayton.ashx (accessed 3 October 2017).

Spigelman J (2006) The principle of open justice: a comparative perspective. University of New South Wales Law Journal 29, 147-166. Available at http://www.austlii.edu.au/au/journals/UNSWLawJl/2006/19.html (accessed 28 September 2017).

Stack R (1998) Courts, Counselors and Correspondents. Littleton, CO: Rothman \& Co. 
Stepniak D (1998) Electronic Media Coverage of Courts: Report Prepared for the Federal Court of Australia. Melbourne: Commonwealth of Australia.

Stoker K and Rawlins BL (2005) The 'light' of publicity in the progressive era. Journalism History 30, 177-188.

Strömbäck J (2008) Four phases of mediatization: an analysis of the mediatization of politics. International Journal of Press/ Politics 13, 228-246.

Supreme Court of Queensland (2016) Electronic Publication of Court Proceedings. April, Brisbane. Available at https://media. sclqld.org.au/documents/news/Electronic-Publication-of-Court-Proceedings.pdf (accessed 21 July 2018).

Supreme Judicial Court Rule (2012) Supreme Judicial Court Rule 1:19: Electronic Access to the Courts, Massachusetts Courts System. Available at http://www.mass.gov/courts/case-legal-res/rules-of-court/sjc/sjc119.html (accessed 20 September 2017). Thompson J (2005) The new visibility theory. Culture and Society 22, 31-51.

Verčič D and Verčič AT (2016) The new publicity: from reflexive to reflective mediatisation. Public Relations Review 42, 493-498.

Wallace A and Johnston J (2015) Tweeting from court: new guidelines for modern media. Media Arts Law Review 20, 15-32.

We Are Social (2017) Digital in 2017: global overview. Available at https:/wearesocial.com/specialreports/digital-in-2017global-overview (accessed 17 January 2018).

West SR (2014) Press exceptionalism. Harvard Law Review 27, 2434-2462.

Williams D (1994) Who Speaks for the Courts, speech at the National Conference on Courts in a Representative Democracy conference, AIJA, Canberra, 13 November.

Zefass A, Verčič D and Wiesenberg M (2016) The dawn of a new golden age for media relations? How PR professionals interact with the mass media and use new collaboration practices. Public Relations Review 42, 499-508.

Cite this article: Johnston J (2018). Three phases of courts' publicity: reconfiguring Bentham's open justice in the twenty-first century. International Journal of Law in Context 14, 525-538. https://doi.org/10.1017/S1744552318000228 